http://ejournal.ihdn.ac.id

\title{
BRAHMAN TATTWA DALAM KENA UPANISAD
}

\author{
Rian Afandi Purnomo \\ Akademisi Institut Hindu Dharma Negeri \\ Email: afandipurnomo@gmail.com
}

\begin{abstract}
Abstrak
Upanisad merupakan susastra kuno yang sangat kaya akan ilmu konsep-konsep ilmu pengetahuan. Upanisad sendiri, adalah bagian yang tidak terpisahkan dari Weda yang menjadi sumber pengetahuan Agama Hindu. Artikel ini secara khusus akan mengulas tentang Brahma Tattwa dalam Kitab Kena Upanisad. Kena Upanisad sendiri merupakan bagian dari Kitab Sama Weda, yang didalamnya membicarakan ilmu pengetahuan tentang Brahman dan Atman. Data artikel ini bersumber dari hasil kajian kepustakaan terhadak Kitab Kena Upanisad. Berdasarkan hasil studi kepustakaan menunjukan bahwa isi pokok Brahma Tattwa dalam Kena Upanisad ini menjelaskan tentang Brahman yang maha tinggi, Brahman tidak dapat dicapai oleh sembarang orang, Brahman bersifat mesiterius, dan kesadaran terhadap Brahman adalah kesadaran yang mengacu pada diri sendiri. Pada dasarnya ajaran Brahma Tattwa dalam Kena Upanisad ialah tentang pengetahuan dan kesadaran tentang Brahman yang kemudian disebut dengan Jnana. Pengetahuan itu sendiri dalam Kena Upansida terbagi menjadi dua yaitu paravidya dan aparavidya. Dalam Kena Upanisad pengetahuan hanya dapat diperoleh melalui panca indera yang kemudian diolah oleh manas dan pada akhirnya menjadi buddhi atau kecerdasan. Meskipun demikian isi pokok dari Kena Upanisad ini telah melampaui ilmu konsep-konsep ilmu pengetahuan modern yang menjdefisikan bahwa pengatahuan adalah pengalaman indera dan memiliki batasan-batasan tertentu.
\end{abstract}

Kata kunci: Brahma tattwa, pengetahuan (jnana),dan kesadaran tertinggi (caitanya). 


\section{PENDAHULUAN}

Kitab Upanisad adalah kitab tak terpisahkan dari kitab suci Weda. Bahkan setiap bagian dari Catur Weda Samhita masing-masing memiliki Upanisad, meskipun dengan jumlah yang berbeda-beda. Dengan posisinya yang sangat penting ini, Upanisad digolongkan ke dalam kitab Sruti dan menjadi sakha atau kitab yang berfungsi untuk menjabarkan isi ajaran Weda sehingga jumlah Upanisad sangat banyak. Juan Mascaro dalam Putra (2010) yang memandang Upanisad sebagai risalah spiritual bahkan harus mengatakan bahwa jika seluruh jumlah Upanisad yang ada saat ini digabungkan dalam satu volume akan membentuk antologi sepanjang Bible. Jika Juan Mascaro menempatkan Upanisad sebagai risalah spiritual, kalangan intelektual Hindu menggolongkan Upanisad sebagai kitab filsafat, terutama karena penjelasannya yang sangat mendalam tentang ketuhanan dan Tuhan (Brahman) itu sendiri, misteri dari realitas tentang jiwa, sorga, neraka, penciptaan, ikatan dan pembebasan, hingga eskatologi. Dengan materi seperti ini, Upanisad sering dianggap kitab yang berat sehingga tidakmudah dipelajari dengan cepat. Namun kerumitannya sedikit dapat diurai dengan penjelasan Upanisad yang dipenuhi perumpamaan, serta yang terpenting narasinya berbentuk dialog dari guru atau maharsi (acarya) kepada muridmuridnya (sisya atau brahmacari).

Dilihat dari kedudukannya di atas, Upanisad menjadi kitab yang tidak asing bagi umat Hindu di Indonesia, lebih khusus di Bali. Popularitasnya berdampingan dengan kitab suci lainnya, seperti Sarasamuscaya, Bhagawadgita dan Manawadharmasastra. Saking populernya, dalam percakapan sehari-sehari, kata Upanisad sering digunakan sebagai pengganti kata ceramah agama, meskipun dalam enam sistem pembinaan umat Hindu atau Sad Dharma yang dikeluarkan Parisada Hindu Dharma Indonesia (PHDI), sudah ada istilah dharmawacana atau dharmatula untuk mewakili syiar agama.

Upanisad sendiri memiliki arti duduk dekat dengan guru. Makna 'duduk dekat di bawah guru' sampai saat ini oleh umat Hindu hanya dipandang sebagai metode belajar, padahal seperti dijelaskan Titib (1996:121), maksud duduk dekat di bawah guru adalah untuk menerima ajaran-ajaran yang bersifat rahasia. Jadi secara substantif, suasana percakapan itu harus mengandung kebutuhan untuk menjadikan proses belajar sebagai metadialog yang tidak bersifat fisik belaka, tetapi kondisi yang amat intim dan tidak berjarak antara acarya dengan sisya. Nilai bhakti akan menjadi jembatan utama yang menghubungkan hati sang acarya dengan sisyanya, sehingga seorang sisya diharapkan dapat mencerap lebih dalam wejangan suci yang diberikan acaryanya, lalu mendialogkannya secara kritis

Berdasarkan pemaparan di atas artikel ini berusaha mengulas tuntas Brahma Tattwa dalam Kena Upanisad. Kena Upanisad menawarkan berbagai ilmu pengetahuan dan cara menadapatkan ilmu pengetahuan. Ilmu pengetahuan yang dimaksud ialah ilmu pengetahuan tentang Brahman. Dalam Kena Upanisad realitas tertinggi atau Brahman dipandang sebagai pengetahuan itu sendiri. Pengetahuan yang harus diperoleh secara komperhensif supaya tidak terjadi kesalahpahaman antara konsep ilmu dengan aksiologi ilmu. Oleh sebab itu Kena Upanisad mengarahkan, dalam penggalian ilmu pengetahuan tersebut perlu menggunakan panca indera. Meski demikian panca indera tidak dapat berdiri sendiri dalam mengkonstruksi pengetahuan yang didapatkan, tetapi perlu adannya bantuan dari manas guna memberikan pertimbangan-pertimbangan yang berarti bagi pengetahuan yang didapatkannya. Hal ini disebabkan karena pengetahuan dibagi menjadi dua kategori yaitu paravidya dan aparavidya. Kedua pengetahuan tersebut yang selalu dijumpai oleh seseorang dalam proses pencarian Brahman.

Artikel ini akan lebih mengkhususkan diri mengarah pada pembahasan terkait Brahma Tattwa atau filsafat tentang Tuhan dalam konsep Kena Upanisad. Tuhan yang merupakan sumber pengetahuan dan sebagai pengetahuan itu sendiri membutuhkan interpretasi dan penelaahan yang menadalam kedalam diri manusia. Oleh sebab itu dalam rangka mengenal dan mengatahui Brahman 
seseorang harus mampu memahami esensi dari dirinya sendiri, karena Brahman juga ada di dalam diri manusia yang disebut sebagai Atman.

\section{PEMBAHASAN}

\subsection{Tentang Kena Upanisad}

Upanisad yang merupakan susastera Weda yang amat mengagumkan, jumlah Upanisad terus mengalami perkembangan sejak dikumpulkan pertama kali. Awalnya, Upanisad berjumlah lebih dari 200 kitab, namun secara tradisi diyakini 108 kitab. Tentang jumlah yang berbeda-beda ini, ada sejumlah pendapat menarik dari para indolog dan orientalis serta intelektual Hindu sendiri. Diskusi itu dimulai dari Muhammad Dara Shikoh yang menerjemahkan Upanisad pada tahun 1656-1657 ke dalam bahasa Parsi, lalu Anquetil Duperron antara tahun 1801-1802 menerjemahkan ke dalam bahasa Latin dengan judul Oupnekhat yang berisi 50 buah kitab.

Kena Upanisad adalah bagian dari Sama Weda dan cabang Thalawakaranya. Dengan demikian Kena Upanisad tidak jarang disebut sebagai Thalawakar Upanisad. Istelah "Kena" sendiri diambil dari kata pertama dari sloka pertama Upanisad tersebut yang berbunyi :"kenesitam patati presitam manaá kena pràóá prathamaá praiti yuktaá. kenesitàý vàcam imàý vadanti, caksuá úrotraý ka u deva" "Atas kemauan dan perintah siapa, pikiran menerangi objeknya.Atas perintah siapa pertamatama daya vital (pràóa) bergerak ? Atas kemauan siapa manusia mengucapkan kata-kata? Kecerdasan apakah yang sesungguhnya mengarahkan mata dan telinga?".

Upanisad ini menjelaskanYang Maha Tinggi, tetapi tanpa mengungkapkan kepribadianNya secara langsung. Yang merupakan tata bahasa dalam kasus "miring". Yang Maha Tinggi adalah "obliquely" diturunkan sebagai inspirer dan pengontrol dari semua fungsi pikiran dan indera dan para dewa. Meskipun tidak secara tegas dikatakan di sini bahwa Brahman bersifat pribadi, Brahman menunjukkan kekuatannya sendiri untuk mengungkapkan diri dan menciptakan kesuksesan bagi individu-individu. Ada empat bab yang berjumlah 34 ayat dan paragraph prosa pendek.

1. Yang Maha tinggi, Brahman, tidak dikenal oleh pikiran dan indera yang memperoleh pengetahuan. Mereka mendapatkan akses mereka berpengetahuan melalui Brahman. Pengetahuan sejati adalah tentang Brahman, bukan apa yang kita lihat di dunia ini.

2. Brahman hanya dapat diketahui sebagian. Seseorang yang mengira dia mengenal Brahman sepenuhnya tidak, sementara orang yang mengakui bahwa dia tidak mengenal Brahman benarbenar tahu sesuatu tentang Brahman.

3. Kisah Brahman menunjukkan diri-Nya sebagai orang misterius (Yakña) kepada para dewa dan membuktikan diri-Nya lebih besar daripada mereka dengan menunjukkan bahwa mereka tidak berdaya di hadirat-Nya.

4. Mereka yang mengenal Brahman sebagaimana Dia telah menyatakan diriNya lebih unggul. Para dewa terbesar adalah mereka yang mengenalnya terlebih dahulu. Agar berhasil dalam hidup, Ia harus disembah, dan penyucian diri diperlukan untuk tujuan ini. Seseorang yang mengenal-Nya akan mencapai kebahagiaan sejati di dunia spiritual.

Berdasarkan klasifikasi di atas dapat dipahami bahwa Kena Upanisad sangat kental akan ajaran theologi Hindu atau yang disebut sebagai Brahma Widya. Pada artikel ini hakikat Brahman akan ditunjukan secara rinci dengan tujuan supaya ajaran brahma widya dalam Kena Upanisad dapat diketahui secara komperhensif.

\subsection{Brahma Tattwa}

Sebelum lebih jauh melangkah mengklasifikasikan dan menginterpretasikan sloka-sloka dari Kena Upanisad yang berkaitan dan Brahma Widya, perlu dipahami bersama terkait pengertian dari Tattwa itu sendiri. 
seperti: kebenaran, kenyataan, hakekat hidup, sifat kondrati, dan segala sumber kebenaran (Watra, 2007: 1). Pada artikel ini lebih memfokuskan pada Tattwadyatmika atau ajaran kebenaran tentang Tuhan. Oleh sebab itu ajaran Tattwa selalu erat kaitanya dengan konsepkonsep ketuhanan atau theologi. Tattwa itu sendiri lebih dekat diartikan dengan kejujuran dan kebenaran. Dalam kitab Kena Upanisad ini, Tattwa adalah satya, satya memiliki arti kebenaran dan kejujuran. Kejujuran dan kebenaran dipandang memiliki sifat yang universal. Kebaikan didalam segala hal positif selalu mengandung kejujuran, kebenaran dan keikhlasan. Dengan demikian untuk mengenali dan mengetahui Tuhan perlu adanya sikap kejujuran dan kebenran atau yang disebut dengan satya.

Tuhan dalam Upanisad disebut Brahman yang memiliki kekuasaan untuk berada di dalam (immanent) dan di luar ciptaanNya (transcendent), seperti udara yang sama berada di dalam dan di luar ruangan. Ia juga ibarat penari dan tariannya. Tuhan itu satu adanya (monotehisme), namun bagi orang suci yang mengetahuinya diberi banyak nama (ekam sat wiprah bahuda wadanti). Ia Maha Ada karena berada di mana-mana dan tak terbatasi oleh apapun (wyapi wyapaka nirwikara), bukan menyepi di satu tempat atau tidak seperti raja yang hanya duduk disinggasana emasnya. Ia Maha Tak Terbatas karena ia dapat mengambil sahasra rupam (1000 wajah) dan sahasra namam (1000 nama), bukan hanya satu bentuk lalu menyembunyikan diri.

Konsep imanen-transenden telah melampui monotheisme yang masih diselimuti sifat-sifat pemarah dan pencemburu seperti laiknya manusia, atau sebaliknya yang penyayang dan pengasih, atau juga bak raja otoriter. Monotehisme absolut menjadikan Tuhan berpihak hanya kepada penyanjungnya, namun memusuhi yang bukan pemujanya. Lebih dari sekadar monotheisme, keberadaan Tuhan dalam Upanisad lebih cenderung sebagai pantheisme yang memandang semuanya adalah
Tuhan, dan Tuhan ada dalam semuanya (sarwam idham kalu Brahman). Ia awal dan akhir dari semuanya namun ia tak berawal dan tak berakhir (anadi ananta). Ia meresapi segalanya, sehingga semuanya adalah Brahman. Brahman dalam Upanisad hanya memiliki sifatsifat satyam (kebenaran), siwam (kebaikan), dan sundaram (keindahan) sehingga ia hanya memberikan kasih sayang kepada semua makhluk hidup. Jika ada pendosa dan menolaknya, Brahman akan mengirimkan ke dunia lagi untuk memperbaiki kesalahannya, bukan menghukumnya ke neraka jahanam.

Narayana adalah Tuhan pada manusia yang hidup dalam hubungan yang abadi dengan nara (manusia). Dia adalah yang abadi yang berdiam dialam yang fana. Manusia perseorangan adalah lebih dari alam semesta. Dia hidup dan merdeka dalam ketidak terbatasan yang tidak bisa di ungkapkan dan juga dalam kesinambuangan kosmis. Kita bisa manunggal dengan kebendaan kosmis melalui cara masuk kedalam kesadaran kosmis, kita menjadi lebih hebat dari semua keberadaan kosmis kalau kita memasuki kesadaran yang mengatasi alam semesta, demikian uraian S. Radhakrishnan. (2008: 48).

\section{a. Panca Indera Sebagai Alat Menerima Pengalaman}

Pada kitab Kena Upanisad yang menjadi alat penerima pengalaman yang paling pertama ialah panca indera. Berasal dari panca inderalah nantinya dikonstruksi kedalam otak sehingga menjadi kecerdasan atau buddhi. Hal tersebut dijelaskan di dalam sloka pembuka dalam Kena Upnaisad yang menyebutkan (Radhakrisna, 2008: 449):

'Apyayantu mamngani vak pranas caksuh srotram atho balam indriyani ca sarvani' Terjemahan:

Semoga anggota ragaku menjadi kuat, begitu juga bicaraku, nafas, mata, hidung, dan juga tenagaku dan juga seluruh indriyaku. 
Kemudian juga semakin diperjelas dalam sloka 1 bagian pertama 1, yang menyebutkan (Radhakrisna, 2008: 450):

"kenesitam patati presitam manaá kena pràóá prathamaá praiti yuktaá. kenesitàý vàcam imàý vadanti, caksuá úrotraý ka u deva'

Terjemahan:

Atas kemauan dan perintah siapa, pikiran menerangi objeknya.Atas perintah siapa pertama-tama daya vital (pràóa) bergerak ? Atas kemauan siapa manusia mengucapkan kata-kata? Kecerdasan apakah yang sesungguhnya mengarahkan mata dan telinga?.

Telinga, kulit, mata, lidah, hidung, kelima indriya ini dapat mengenali suara, sentuhan (raba), bentuk, rasa (kecap), dan bau yang merupakan objek-objek pengetahuan dan hanya dapat diketahui oleh kelima indriya tersebut. Alam semesta dialami melalui peralatan ini yang berdiri di tengah-tengah antara yang mengetahui dan yang dapat diketahui. Kemampuan untuk memahami objekobjek tersebut, dinamakan pikiran atau manas. Manas bergerak ke luar melalui jñànendriya yang dikatakan terdahulu dan mengikatkan dirinya pada objek dan berbarengan pada saat peristiwa itu pula, manas mengambil bentuk objek tersebut dan inilah yang disebut wåtti atau fungsi. Manas adalah acetana sehingga perubahan dan pemakaian, atau wikàrajuga acetana, yaitu tanpa kecerdasan dan tidak vital. Sebuah boneka kayu hanya memiliki bahan kayu, demikian pula sebuah boneka gula-gula yang hanya memiliki gula. Manas yang acetana tak dapat mencapai pengetahuan cetana atau kecerdasan tertinggi yang meresapi alam semesta.

Telinga memiliki kemampuan untuk mengetahui suara, mata diberi kemampuan untuk mengetahui dan membedakan bentuk. Indriya lainnya juga diperlengkapi secara demikian. Bila manas melalui indriya pengetahuan, mengamati suatu objek, kamu memperoleh pengetahuan tentang objek tersebut. Oleh karena itu, kelima indriya dan manas, semuanya merupakan peralatan pengetahuan. Bagaimana mereka dapat mengatur pelaksanaan fungsi cerdik ini, pada hal mereka sendiri tanpa kecerdasan ? Jawabannya adalah : Akibat adanya àtma dan akibat dari pantulan kecemerlangan àtma pada antah karana. Matahari menyinari alam semesta dan mengaktifkannya dalam ribuan cara. Demikian pula àtma, dengan tejaNya, mengaktifkan oleh àtma, seperti arus listrik yang memberi daya pada mesin-mesin dan bermacam-macam peralatan cetak dan sebagainya tetapi tak terlihat. Arus listrik adalah si penggerak dari gerakan, dan merupakan mesinnya mesin. Demikian pula àtmik teja yang merupakan telinganya telinga, matanya mata, yang merupakan arus pengaktif.

Seperti kereta yang tanpa kecerdasan diarahkan oleh seorang kusir, seharusnya ada seorang kusir yang mengarahkanmanas yang tanpa kecerdasan yang duduk di sana dan memilikinya sebagai sebuah kendaraan. Daya penggerak yang mengaktifkan peralatan dalam, indriya gerak, indriya pengetahuan, lima pràóa semuanya itu adalah Tuhan. Pertanyaan yang diajukan di atas mencantumkan bahwa daya-daya ini berbeda dengan indriya. Oleh karena itu, secara alami mestinya si penggerak keseluruhan kumpulan indriya ini berbeda dari manas, bukan? Mereka yang ingin mengetahui Yang Abadi, yakin bahwa semua kegiatan dan gerak, cepat berlalunya sehingga ia tidak khawatir tentang yang abadi.Kesatuan yang abadi itu tanpa hasutan, sehingga ia tak bergerak oleh dorongan yang tiga jenis itu. Ia tidak memerintahkan indriya-indriya guna keperluan yang ini maupun yang itu.

\section{b. Brahman dan Atman}

Memahami konsep atman (roh) dalam kitab Upanisad diperlukan kemampuan ekstra, yaitu suatu kemampuan diluar batas jangkauan 
intelektual, karena kedalaman bahasanya sangat sulit diukur dengan ilmu pengetahuan intelektual. Selain itu tata bahasa dan kosa kata yang demikian kaya membuat si pembaca linglung, jadi diperlukan seorang guru sepiritual yang maampu menuntun si pembaca.

Atman yang sesungguhnya adalah atman yang mutlak yang bukan golongan dari metafisik yang abstrak, tetapi atman rohani yang asli. Bentuk apapun yang lain adalah yang kebradaan yang dijjadikan objek. Atman adalah yang hidup dan bukan objek. Ini adalah pengalaman dimana atman adalah subjek yang maha tahu pada saat yang bersamaan objek yang diketahui. Atman hanya terbuka untuk atman. Atman bukan kenyataan yang objektif, bukan pula sesuatu yang berupa subjektif murni. Hubungan subjek - objek hanya mempunyaiarti dalam dunia objek - objek / dalam lingkungan pengetahuam dalam arti luas. Atman adlah cahayanya cahaya dan melalui hal ini sajalah ada cahaya didalam alam semesta. Dia adalah cahaya abadi, dia adalah yang tiada hidup atau mati, yang tanpa gerak atau perubahan yang masih bertahan ketika yang lainya sudah berakhir.

Badan bagi Atma, atau untuk menyederhanakannya disebut jiwa, bukanlah penjara yang mengekangnya, seperti anggapan Plato di masa Yunani kuno. Badan terbuat dari prakerti atau potensi materi yang berasal dari Tuhan sendiri. Badan bersifat sementara, tidak seperti jiwa yang kekal dan abadi, bahkan ketika badan sudah rusak dan mati. Inti manusia adalah tentang jiwanya, atman atau sang diri yang menggerakkan badan, yang dalam Upanisad disebut berasal dan bagian tak terpisahkan dari Brahman itu sendiri. Tat Twam Asi yang artinya ITU (Tuhan) adalah Engkau, lahir dari konsep ini yang jika mampu direalisasikan maka manusia berhak menyebut dirinya "Aku adalah Tuhan" itu sendiri (Brahma Aham Asmi). Manusia pada level Brahma Aham Asmi akan melihat semuanya menjadi sama, menghargai semua makhluk hidup, tidak menyakiti dan membunuh karena ia melihat jiwa yang sama dalam setiap makhluk. Ada Tuhan yang sama dengan dirinya (Segara, 2016: 145).Kena Upanisad dalam sloka 5 bagian 1 (Radhakrisna, 2008: 451) menyebutkan:

'Yad vaca nabhuyaditam yena vag abhuyudyate.

Tad eva brahman tvam vidhi nedam yad idam upasate'.

Sesuatu yang tiak dinyatakan dalam wicara tetapi sesuatu dengan apa wicara itu dinyatakan, ketahuilah bahwa itulah sesungguhnya Brahman bukan seperti yang dipuja orang.

Meskipun Atman dan Brahman itu sama, namun terdapat titik perbadaan yang tidak dapat dielakan begitu saja. Sloka di atas menjelaskan bahwa antara Brahman yang mutlak adalah Atman yang ada dalam diri atau yang disebut sebagai Isvara. Isvara sebagai roh yang bersemayam dalam tubuh mahlik hidup. Oleh sebab itu dalam Kena Upanisad Brahman juga ada dalam seluruh ciptaannya atau yang kemudian disebutkan dalam konsep imanen dan transenden.

Dengan demikian dapat dipahami bahwa Brahman dan Atman adalah satu keterhubungan yang tidak pernah putus. Ketika mempelajari Brahman maka secara tidak langsung juga mempelajari Atman bahkan sebaliknyapun demikian. Namun ada titik tertentu yang menjadi pembeda dalam mempelajari Brahman dan Atman. Dan bahkan pengetahuan itu adalah Brahman. Selain itu pengetahuan tentang Brahman itu menipu, terkadang apa yang disebut dengan pengetahuan itu bukanlah Brahman, sehingga banyak pihak yang salah tafsir akan hal tersebut. Keadaan ini terjadi disebabkan karena Brahman itu tidak pernah dapat terfikirkan (Acintya). Kena Upanisad dalam sloka 6 bagian 1 (Radhakrisna, 2008: 451) menyebutkan:

yad manasa na manute yenahur mano matam.

Tad eva brahma tvam viddhi nedam yad idam upasate.'

Terjemahan:

Hal itu yang tidak dipikirkan oleh pikiran 
(manas) tetapi dengan apa mereka katakan

pikiran itu dipikirkan (berpikir) ketahuilah bahwa itu sesungguhnya adalah Brahman dan bukan apa yang dipuja orang.

Sloka di atas menunjukan bahwa Tuhan atau Brahman adalah suatu realitas tertinggi yang sangat sulit dicapai dan pencapaian itu bisa terjadi secara tidak sengaja. Hal ini terjadi karena Brahman sangat sulit untuk dipikirkan bahkan tak terpikirkan (Acintya). Oleh sebab itu dalam belajar pengetahuan tentang Brahman seseorang harus terlebih dahulu mengenali dirinya sendiri, karena di dalam dirinyalah Brahman yang dalam wujud Atman dan sering disebut sebagai Isvara bersemayam dan menjadi sumber kehidupan. Dengan demikian konsep "Aham Brahman Asmi" dalam ajaran ini sangat kentara sekali, yang mana Tuhan dan Manusia adalah satu kesatuan yang tunggal. Meskipun demikian tidak bermaksud mempersekutukan Tuhan sebagai mahluk yang tidak sempurna dan penuh dengan kelalaian.

\section{c. Brahman Sebagai Pengetahuan Tertinggi}

Pada kitab Kena Upanisad ini, kehidupan yang utama ialah kehidupan yang mampu memahami realitas tertinggi atau Brahman. Orangorang yang melakukan ini sering disebut sebagai seorang Brahmajnani.Seorang Brahmajñàni, pertentangan antara dharma danadharma, jasa dan ganjaran, tidak ada. Ia harus mencari untuk memetik tali yang membelenggu hati kepada dunia objektif ini. Dengan demikian, ia menginginkan suatu jawaban terhadap pertanyaan, yang menjadi awal dariUpanisad ini : Dengan apa pikiran mencapai benda-benda, dan sebagainya ? Untuk mencapai Brahma-Jñàna, tapas, pengendalian diri, upacara Weda, pemujaan gambaran Tuhan, semuanya merupakan bantuan yang baik. Jñàna memiliki lokasi pada satya. Hal ini dengan jelas disebutkan dalam sloka Kena Upanisad 8 bagian 4 (Radhakrisna, 2008: 458) yang menyebutkan bahwa:

'Tasyaitapo-dama-karmeti pratistha, vedah sarvangani, satyam ayatanam,
Tapa, pengendalian diri dan perbuatan adalah penopangnya; weda adalah semua satuan-satuanya; kebenaran adalah tempat bersemayamnya.

Sloka di atas menjelaskan bahwa Brahman hanyalah bisa dicapai dengan cara melakukan tapa maupun pengendalian diri yang sangat kompleks. Keterikan indera akan duniawi menyebabkan seseorang semakin kehilangan arah dan semakin jauh dari realitas tertinggi dari Tuhan. Oleh sebab itu seseorang dituntut untuk mampu menjaga dan mengekang semua bentuk keterikatan dualistik tersebut, seperti halanya dharma dan adharma. Brahman dan pengetahuan itu sendiri adalah entitas yang satu. Brahman adalah jñànam itu sendiri, sehingga tak akan pernah "diketahui" oleh seorang "yang mengetahui". Dengan proses mengetahui, hal-hal lain dapat diketahui, tetapi bukan pengetahuan itu sendiri. Lampu tak akan menghendaki lampu lain untuk melihat dirinya, ataupun menghendaki sinarnya sendiri. Ia memiliki sinar pada objek lainnya dan ia tidak mengharapkan sinar pada sinarnya sendiri; demikian pula kamu merupakan sinar, yaitu àtma Àtma pada dirimu memiliki sifat yang sama dengan àtma pada semua makhluk; yang satusatunya merupakan realitas, yang tak memiliki batasan atau atribut, ataupun kualifikasi.

Àtma dapat dikenali dengan belajar Úàstra, dan dengan mengikuti pesanpesan yang terdapat di sana. Yang tak dapat disinari dengan kata-kata atau wacana, ataupun dengan indriya-indriya; yang menyinari kata-kata dan semua indriya, itulah Brahman, atau àtma. Kanda pertama dari Upanîuad ini menjelaskan bahwa Brahman tak mampu dibatasi, dikesampingkan ataupun dilalaikan. Karena itu, bagi mereka yang menyatakan bahwa mereka telah melihat Brahman, "Ia" belum merupakan suatu subjek penyelidikan dan pencarian selanjutnya. Mereka belum mencapai tahap akhir, karena hal itu bukan jñàna murni, tetapi merupakan suatu tipuan. Àtma seseorang yang mengetahui, sesungguhnya adalah Brahman itu sendiri, yang 
raguan, bukan ? Api tak dapat membakar dirinya sendiri, lalu bagaimana dapat àtma mengetahui àtma; bagaimana yang mengetahui dapat mengetahui dirinya sendiri ? Oleh karena itu, pertanyaan : Aku telah mengetahui Brahman, menandakan bahwa itu merupakan tipuan dan bukan pengetahuan yang sesungguhnya.

Brahman memiliki berbagai bentuk yang dapat dikenali dan dapat dihitung; namun hal itu hanya dalam batasan indriya yang dikualifikasikan dengan namadan rùpa. Dengan sendirinya yang Mutlak tak memiliki suara, bau, rasa, raba ataupun wujud tetapi ada selamanya. Dalam kegiatan apa pun kamu menyadari keberadaanNya, kegiatan itu memberi ciri-ciri yang layak, dan dalam keadaan bagaimanapun sàstra sàstra didiskusikan dan ditentukan, keadaan itu menjadi sàstra khusus pencirian tentangBrahman . Kesadaran (Caitanya) yang menjadi jelas apabila dibatasi dengan ikatan atau wadah tertentu, maka Caitanyaadalah Brahman. Caitanya itu tanpa keterikatan, namun apabila dibayangkan dengan objek seperti badan fisik, maka Ia memberikan kesan bahwa Ia terikat. Dari kenyataan bahwa apabila air disebuah danau dikacaukan, gambaran (bayangan) matahari dipermukaan air bergoyang, kamu tidak dapat menyimpulkan bahwa matahari di langit, yang jauh dan terpencil, juga bergoyang. Matahari dan lapisan air di danau tak berhubungan, dan tak ada hubungan yang dapat dikenakan antara keduanya. Demikian juga badan apabila mengalami pertumbuhan, merosot, hancur, dan sebagainya yang memberikan kesan bahwa àtma juga berakibat demikian; tetapi àtma tak terpengaruh sama sekali.

Brahmanmelampaui pencapaian dari kecerdasan si pengamat, dan hanya dapat dicapai oleh mereka yang membuang kecerdasannya sebagai suatu alat yang tak berguna. Hanya pengalaman saja yang merupakan cara pendekatan pembuktian dan hasil. Keadaan terakhir dari Brahma-Jñànamerupakan akhir dari semua pencarian dan semua penyelidikan. Realisasi aktual atau Sàkîàtkàra merupakan hasilnya.

YOGA DAN KESEHATAN Volume 2, No.2 Desember 2019 dalam samàdhi, penenangan dari segala hasutan dalam segala tingkatan kesadaran, yang tentu saja sebelumnya didahului dengan srawada. Manana dan nididhyàsana yang dibantu buddhi atau kecerdasan. Seseorang akan mendapat Satyaswarùpa, apabila ia memahami sifat dari àtma; dan bila tidak, hal itu merupakan kehilangan yang besar. Seorang jũànì mengenalinya pada setiap makhluk hidup dan pada setiap objek, prinsip dari àtma yang meresapi segalanya, dan bila ia meninggalkan dunia ini, ia menjadi terbebas dari kelahiran dan kematian. Brahma Tattwa adalah aspek tertinggi dalam kehidupan. Melalui Brahma Tattwa inilah seseorang dapat terlebas dari lingkaran inkarnasi. Hal tersebut dengan jelas disebutkan dalam kitab Kena Upanisad sloka 9 bagian 4 (Radhakrisna, 2008: 459), yang tertulis sebagai berikut.

\section{'yo va eta evam vedapahatya ante svarga loke \\ jyeye prathitisthati, prathitisthati'}

Terjemahan:

Siapa yang mengerti hal ini, dialah yang sesungguhnya mengalahakan dosa, dan pada akhirnya akan dengan kukuh berdiri pada dunia Yang Maha Tinggi si swarga, ya dia berdiri dengan tegap.

Berdasarkan sloka si atas dapat dipahami bahwa pengetahuan Brahman merupakan sebuah aspek yang tidak terbatas dan pada akhirnya seseorang yang mempelajarinya atau yang disebut sebagai brahmajnani akan terbebas dari segala ikatan, bahkan dosa. Keadaan yang bersifat tanpa batas tersebut dalam konsep Kena Upanisad sering disebut sebagai sorga. Dengan demikian kata kta sorga dalam Kena Upanisad bukan berarti sebagai ruang kehidupan setelah kematian, melainkan sebagai sebuah keadaan yang tanpa ada ikatan duniawi, terlepas dari batas-batas kesengan maupun kesedihan. Selain itu sorga dalam Kena Upanisad diasosiasikan sebagai sebuah kebahaagiaan yang tanpa batas dan tidak pernah lagi terikat ke dalam unsur-unsur duniawian 
bahkan setelah kematian Atman tidak lagi kembali ke dalam badan material. Itulah keutamaan Brahma Tattwa, yang mampu memberikan kebebasan dan kelepasan akan lingkaran inkarnasi atau samkara punarbhawa.

\section{SIMPULAN}

Pada dasarnya Kena Upanisad adalah bagian dari Sama Weda. Kena Upanisad lebih memfokuskan tentang ajaran atau ilmu pengetahuan tentang Tuhan. Dalam pencarian pengetahuan Kena Upanisad menyebutkan hanya dapat dilakukan oleh panca indera yang kemudian dibantu oleh pikiran (manas) dan berakhir menjadi sebuah kecerdasan (Buddhi). Melalui Kena Upanisad entitas Tuhan dengan Atman dapat dibedakan secara detail. Pembeda antara keduanya ialah pada aspek epistemologinya, yaitu cara pengenalanya. Sehingga jelas bahwa Brahman dan Atman adalah suatu aspek yang berbeda. Namun perbedaan itu seakan hilang ketika sang Atman sudah mencapai pencerahan dan kesadaran (Caitanya) akan realitas tertinggi. Oleh sebab itu dalam Kena Upanisad juga dikenal konsep "Aham Brahman Asmi" bahwa "aku adalah Tuhan. Maksud dari konsep tersebut ialah adanya kesatuan antara Tuhan dengan Atman yang telah mencapai kesadaran tertinggi (Caitanya) yang kemudian disebut sebagai Isvara. Bagi seseorang yang mendalami Brahma Tattwa disebut sebagai brahmajnani. Seorang brahmajnani yang telah mampu menyempurnakan ilmu pengetahuannnya tentang realitas tertinggi Tuhan maka dia akan mencapai sorga dan terlepas dari lingkaran inkarnasi.

\section{Daftar pustaka}

Titib, I Made, 1996. Weda Sabda Suci Pedoman Praktis Kehidupan. Surabaya: Paramita.

Watra, I Wayan. 2007. Pengantar Filsafat Hindu (Tattwa I). Surabaya: Paramita.

Radhakrishna. S. 2008. Upanisad-upanisad Utama. Surabaya: Paramita.

Segara, I Nyoman Yoga. 2016. "Duduk Dekat di Bawah Guru" dan Transformasinya: Kajian atas Kitab Upanisad dalam Ajaran
Hindu. Jurnal Lektur Keagamaan.Vol.14. Nomor 1. Halaman 135-152. 